\title{
THE CO-ADSORPTION OF HYDROGEN AND CARBON DIOXIDE ON CATALYSTS
}

\author{
TÍMEA SÜLI-ZAKAR \\ University of Szeged Faculty of Agriculture \\ Institute of Crop Production and Environmental Protection \\ Andrássy út 15, 6800 Hódmezővásárhely, Hungary \\ sulizakartimea@mgk.u-szeged.hu
}

\begin{abstract}
In the elucidation of the reaction mechanism of a catalytic process it is important to establish the reaction intermediates and their possible role in the reaction. In most cases, however, this is not an easy task as a real reaction intermediate exists only transitorily and in a very low concentration on the catalysts.

The adsorption of $\mathrm{CO}_{2}$ and the co-adsorption of $\mathrm{H}_{2}+\mathrm{CO}_{2}$ on $\mathrm{Re}$ supported by $\mathrm{Al}_{2} \mathrm{O}_{3}, \mathrm{TiO}_{2}, \mathrm{MgO}$ and $\mathrm{SiO}_{2}$ have been investigated by FT-IR spectroscopy. The dissociation of $\mathrm{CO}_{2}$ was not experienced on the $\mathrm{Re} / \mathrm{Al}_{2} \mathrm{O}_{3}$ reduced at $673 \mathrm{~K}$, it occurred, however, on the sample reduced at $1073 \mathrm{~K}$. Addition of $\mathrm{H}_{2}$ to $\mathrm{CO}_{2}$, initiated the dissociation on all catalysts as indicated by CO bands at 2022-2053 $\mathrm{cm}^{-1}$. Besides, new spectral features were developed at 1600-1550, 1395 and $1365 \mathrm{~cm}^{-1}$ attributed to format species. No bands due to format were detected on $\mathrm{Re} / \mathrm{SiO}_{2}$ and no format was detected following the co-adsorption of $\mathrm{CO}_{2}$-containing gas mixture on the supporting oxides alone. It was assumed that the format species identified in the surface interactions is located on the support, where it is stabilized. The possible pathways of the occurrence of format complex on the oxides are described.
\end{abstract}

Keywords: catalyst, support, co-adsorption, $\mathrm{H}_{2}+\mathrm{CO}_{2}$ reaction, formate

\section{INTRODUCTION}

The number of chemical products produced in the world moves about 30,000 nowadays (WEISSERMEL AND ARPE, 1997, ARPE, 2010). But despite the relatively large numbers, they are just made from a few raw materials. The applied coal is obtained almost exclusively from fossil sources - namely, mineral oil, natural gas and hard coal.

The limited resources of coal raised the problem of the exploitation of alternative carbon sources in the early 1970s. Carbon dioxide has always enjoyed great attention because of the nature of synthetic building process used successfully during photosynthesis - which can be considered as the basis of life on Earth as well. In our planet the amount of $\mathrm{CO}_{2}$ and $\mathrm{CO}_{3}{ }^{2-}$ forms are available several times higher than natural resources in the form of hard coal, oil or natural gas form. In addition, this source is virtually limitless, especially if we consider that since the middle of the 19th century at the beginning of industrialization - the amount of "anthropogenic" $\mathrm{CO}_{2}$ has multiplied considerably in the atmosphere. (In 1989 the amount of $\mathrm{CO}_{2}$ emission due to industrial activities was approximately $7 \times 10^{9} \mathrm{t}$ (LEITNER, 1995).

Supported Re is a widely used catalyst in several technologically important reactions, such as the reforming of petroleum feedstock (CIAPETTA AND WALLANCE, 1971). Re also exhibits oxygen storage properties in automatic three-way catalysts (TAYLOR ET AL., 1984).

\section{MATERIAL AND METHOD}

Supported rhenium was prepared by impregnating the support in aqueous solution of $\left(\mathrm{NH}_{4}\right)_{2} \mathrm{ReO}_{4} 4 \mathrm{H}_{2} \mathrm{O}$ (Merck). The following supports were used: $\mathrm{SiO}_{2}(\mathrm{CAB}-\mathrm{O}-\mathrm{SiL}$, and MS 
Scintran BHD); $\mathrm{Al}_{2} \mathrm{O}_{3}$ (Degussa); $\mathrm{TiO}_{2}$ (Degussa $\mathrm{P} 25$ ) and $\mathrm{MgO}$ (DAB). After impregnation, the suspensions were dried in air at $383 \mathrm{~K}$. The dried and pulverized samples were pressed into thin self-supporting wafers $\left(30 \mathrm{~mm} \times 10 \mathrm{~mm}, \sim 60 \mathrm{mg} / \mathrm{cm}^{2}\right)$. Further treatment was applied in situ: it consisted of oxidation at $573 \mathrm{~K}\left(100\right.$ Torr of $\mathrm{O}_{2}$ for 30 $\mathrm{min}$ ), evacuation at $573 \mathrm{~K}$ for $30 \mathrm{~min}$, reduction at $673 \mathrm{~K}$ and in certain cases at 973-1073 $\mathrm{K}$ (100 Torr of $\mathrm{H}_{2}$ for $\left.60 \mathrm{~min}\right)$, and evacuation at the temperature of reduction for $30 \mathrm{~min}$. Note that the heating of the sample from $573 \mathrm{~K}$ to the temperature of reduction was carried out in the presence of hydrogen. As hydrogen can promote the dissociation of $\mathrm{CO}_{2}$ (see next chapter), it was absolutely necessary to remove completely the hydrogen from the system after the reduction of Re catalyst, otherwise the appearance of $\mathrm{CO}$ bands cannot be avoided. The Re content was $5 \mathrm{wt} \%$ on all samples.

Infrared spectra were recorded with a Digilab. Div. FTS 155 by Biorad with a wave number accuracy of $\pm 4 \mathrm{~cm}^{-1}$ (Figure 1). Typically 128 scans were collected. All of the spectra were taken without the use of a scaling factor $(f=1.0)$.

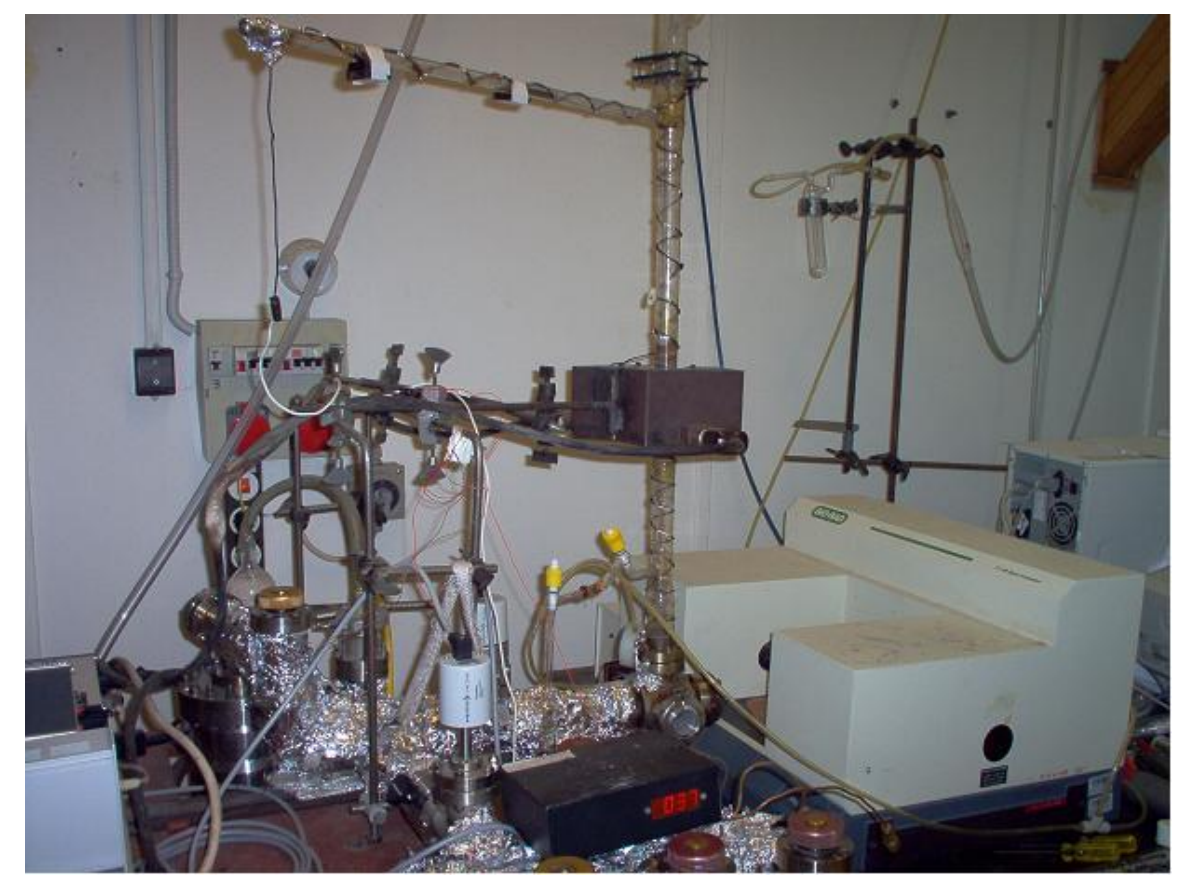

Figure 1. FTIR 155 set

\section{RESULTS}

\section{$\mathrm{CO}_{2}$ adsorption}

The spectra obtained after adsorption of $\mathrm{CO}_{2}$ on $\mathrm{Re} / \mathrm{Al}_{2} \mathrm{O}_{3}\left(\mathrm{~T}_{\mathrm{R}}=673 \mathrm{~K}\right)$ are displayed in Figure $2 A$.

Strong bands appeared at 2334, 1646, 1481, 1443 and $1232 \mathrm{~cm}^{-1}$. The intensity of which only slightly decreased after degassing at $300 \mathrm{~K}$. There were no other spectral features following the adsorption at higher temperatures, 373-673 K. Similar experiment on the $\mathrm{Re} / \mathrm{Al}_{2} \mathrm{O}_{3}$ reduced at $1073 \mathrm{~K}$ produced a weak absorption band at $2040 \mathrm{~cm}^{-1}$, in addition to the previously observed peaks (Figure $2 B$ ). For $\mathrm{Re} / \mathrm{MgO}$, we measured absorption at 2334, 1660-1670, 1450,1543, 1310 and $1220 \mathrm{~cm}^{-1}$ at $300 \mathrm{~K}$. Admission of $\mathrm{CO}_{2}$ on 
$\mathrm{Re} / \mathrm{TiO}_{2}$ at $300 \mathrm{~K}$ produced bands at 2334, 1667, 1582, 1438, 1378 and $1322 \mathrm{~cm}^{-1}$. The position of which was independent of the temperature in the range of 300-573 K. In the case of $\mathrm{Re} / \mathrm{SiO}_{2}$, we obtained only a band at $2334 \mathrm{~cm}^{-1}$. Evacuation of the cell led to the elimination of the $2334 \mathrm{~cm}^{-1}$ feature in all cases, but did not affect the other bands.
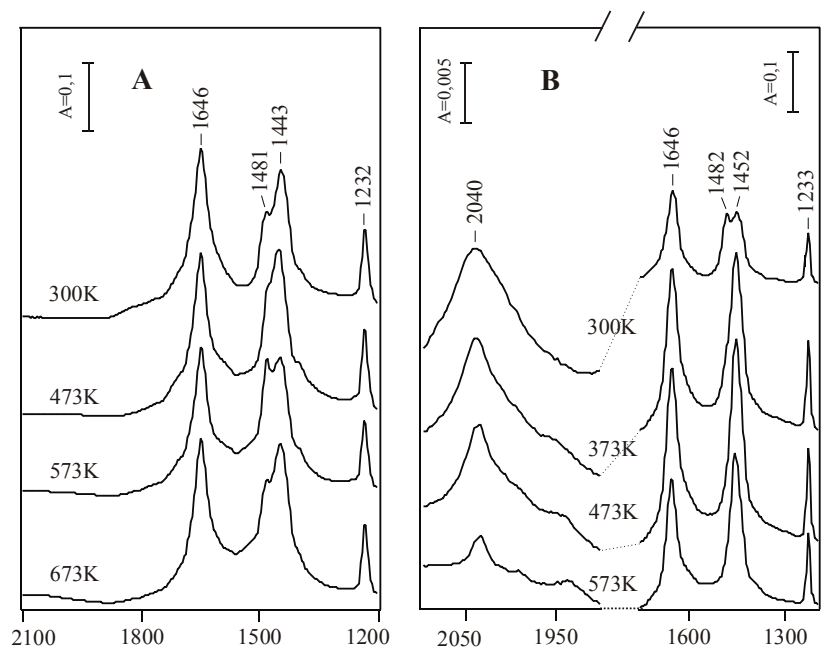

Wavenumber $\left(\mathrm{cm}^{-1}\right)$

Figure 2. FTIR spectra of $\mathrm{Re} / \mathrm{Al}_{2} \mathrm{O}_{3}$ following the adsorption of $\mathrm{CO}_{2}$ (50 Torr) at different temperatures for $15 \mathrm{~min}\left(\mathrm{~T}_{\mathrm{R}}=673 \mathrm{~K}\right)$ Reduction temperature: $673 \mathrm{~K}(\mathrm{~A})$ and $1073 \mathrm{~K}(\mathrm{~B})$.

$\mathrm{H}_{2}+\mathrm{CO}_{2}$ adsorption

Adding $\mathrm{H}_{2}$ to $\mathrm{CO}_{2}$ caused a change in the IR spectra of adsorbed $\mathrm{CO}_{2}$ registered by $\mathrm{Re} / \mathrm{Al}_{2} \mathrm{O}_{3}\left(\mathrm{~T}_{\mathrm{R}}=673 \mathrm{~K}\right)$ (Figure $\left.3 A\right)$.
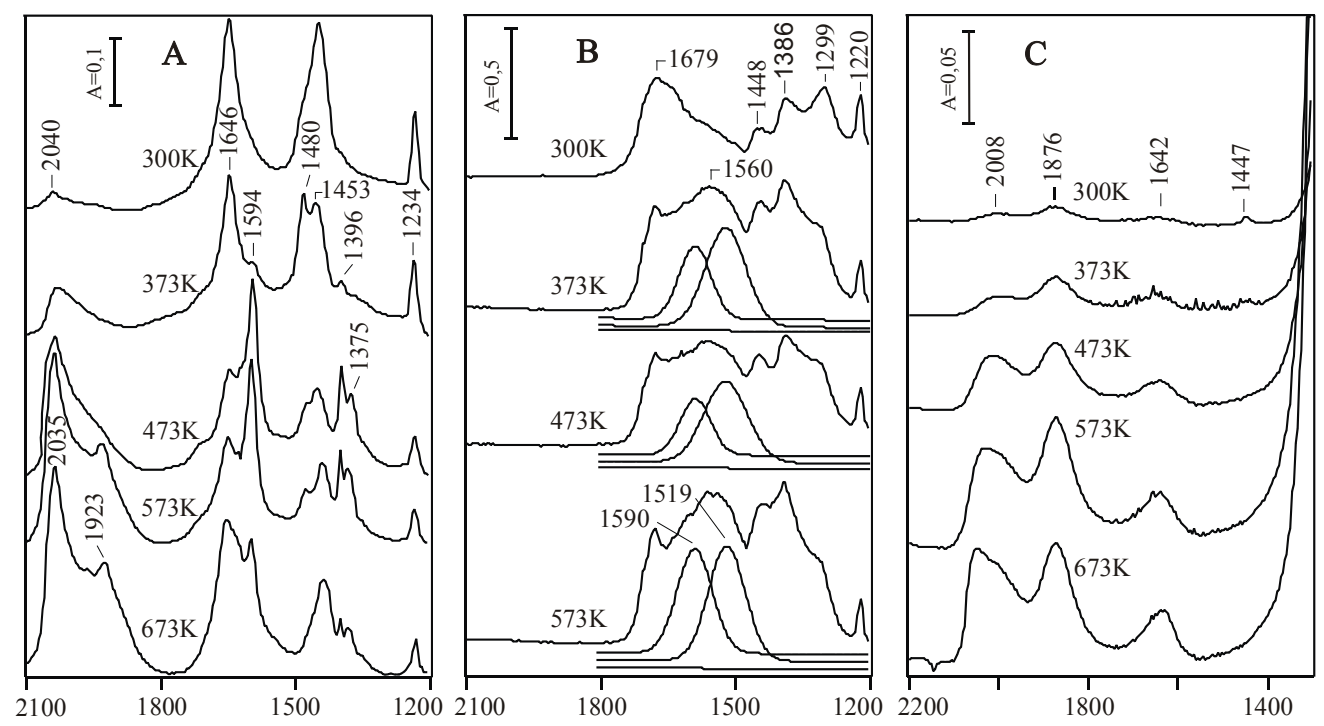

Wavenumber $\left(\mathrm{cm}^{-1}\right)$

Figure 3. FTIR spectra of $\mathrm{Re}$ catalysts following the adsorption of $\mathrm{H}_{2}+\mathrm{CO}_{2}(1: 1)$ at different temperatures for $15 \mathrm{~min}\left(T_{R}=673 \mathrm{~K}\right)$

Supports: $\mathrm{Re} / \mathrm{Al}_{2} \mathrm{O}_{3}(\mathrm{~A}) ; \mathrm{Re} / \mathrm{MgO}(\mathrm{B}) ; \mathrm{Re} / \mathrm{SiO}_{2}(\mathrm{C})$ 
In consequence of the bands of various carbonates detected after $\mathrm{CO}_{2}$ adsorption, new spectral features appeared at 2040,1594, 1396 and $1375 \mathrm{~cm}^{-1}$. These new bands were seen even after adsorption at $300 \mathrm{~K}$ : their intensities increased in time of the adsorption. Raising the temperature resulted in an enhancement of all new bands, and produced another peak at $1923 \mathrm{~cm}^{-1}$. Note that we also obtained a very weak signal at $2873 \mathrm{~cm}^{-1}$. Degassing the catalyst at $300 \mathrm{~K}$ after above experiments caused a slight reduction of the bands in the low frequency region.

Co-adsorption of $\mathrm{H}_{2}+\mathrm{CO}_{2}$ on $\mathrm{Re} / \mathrm{MgO}$ yielded no bands in the $\mathrm{CO}$ stretching region. In the low frequency range a broad absorption was observed between 1500 and $1650 \mathrm{~cm}^{-1}$ consisting of several components. Deconvolution of this broad peak resulted in at least two bands between 1519 and $1590 \mathrm{~cm}^{-1}$ (Figure 3B).

In the case of $\mathrm{Re} / \mathrm{SiO}_{2}$ weaker absorption bands appeared at 2008 and $1876 \mathrm{~cm}^{-1}$ at $300 \mathrm{~K}$. An increase in the temperature caused an intensification and a slight shift of these bands (Figure 3C).

It is important to note that no new spectral features developed in the low frequency region. In certain cases a band was seen at $\sim 1620 \mathrm{~cm}^{-1}$, which is very likely due to the adsorbed $\mathrm{H}_{2} \mathrm{O}$.

Compared the production of new spectral features, $\mathrm{Re} / \mathrm{TiO}_{2}$ was more active than $\mathrm{Re} / \mathrm{Al}_{2} \mathrm{O}_{3}$. Strong absorption bands appeared even at room temperature. Their positions were at 2053, 2010 and $1976 \mathrm{~cm}^{-1}$ (Figure 4). An increase in the temperature caused a shift of the $2053 \mathrm{~cm}^{-1}$ band first to 2043 and then $2037 \mathrm{~cm}^{-1}$, the disappearance of the bands at 2010 and $1976 \mathrm{~cm}^{-1}$, and the formation of new band at $1944 \mathrm{~cm}^{-1}$. In the low frequency region a band at $1583 \mathrm{~cm}^{-1}$ formed after $\mathrm{CO}_{2}$ adsorption is broadened, particularly at 373$473 \mathrm{~K}$. It clearly consisted of two components absorbing at 1585 and $1547-1550 \mathrm{~cm}^{-1}$. At the same time another weak peak developed at $1360 \mathrm{~cm}^{-1}$. It is an important observation that the co-adsorption of $\mathrm{H}_{2}+\mathrm{CO}_{2}$ mixture on Re-free oxides did not produce the 15901595 and $1360-1395 \mathrm{~cm}^{-1}$ spectral features under similar conditions up to $573 \mathrm{~K}$.

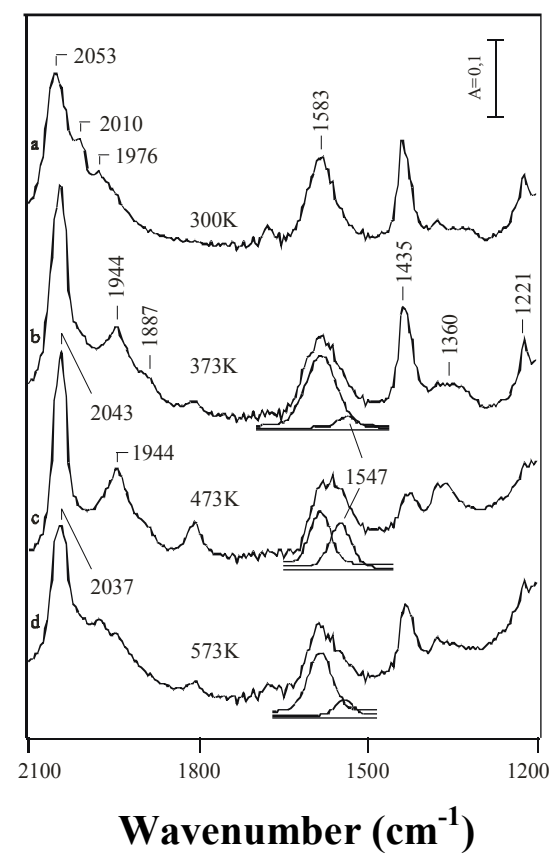

Figure 4. FTIR spectra of $\mathrm{Re} / \mathrm{TiO}_{2}$ following the adsorption of $\mathrm{H}_{2}+\mathrm{CO}_{2}(1: 1)$ at different temperatures for $15 \mathrm{~min}\left(\mathrm{~T}_{\mathrm{R}}=673 \mathrm{~K}\right)$ 


\section{CONCLUSIONS}

The adsorption of $\mathrm{CO}_{2}$ on $\mathrm{Re}$ supported by $\mathrm{Al}_{2} \mathrm{O}_{3}, \mathrm{TiO}_{2}, \mathrm{MgO}$ and $\mathrm{SiO}_{2}$ have been investigated by FT-IR spectroscopy. The dissociation of $\mathrm{CO}_{2}$ was not experienced on the $\mathrm{Re} / \mathrm{Al}_{2} \mathrm{O}_{3}$ reduced at $673 \mathrm{~K}$, it occurred, however, on the sample reduced at $1073 \mathrm{~K}$.

No format was detected following the co-adsorption of $\mathrm{CO}_{2}$-containing gas mixture on the supporting oxides alone. It was assumed that the format species identified in the surface interactions is located on the support, where it is stabilized.

Addition of $\mathrm{H}_{2}$ to $\mathrm{CO}_{2}$, initiated the dissociation on all catalysts as indicated by $\mathrm{CO}$ bands at $2022-2053 \mathrm{~cm}^{-1}$. Besides, new spectral features were developed at $1600-1550,1395$ and $1365 \mathrm{~cm}^{-1}$ attributed to format species. This assumption was confirmed by the adsorption of $\mathrm{HCOOH}$ vapor on these solids.

\section{REFERENCES}

ARPE, H.J. (2010): Industrial Organic Chemistry, 5th ed., VCH, Weinheim. 525 p.

Ciapetta F. G., Wallace D.N. (1971): Catalytic Naphtha Reforming. Catal. Rev. 5: 67.

LEITNER W. (1995): Carbon Dioxide as a Raw Material: The Synthesis of Formic Acid and Its Derivatives from $\mathrm{CO}_{2}$. Angew. Chem. 34: 2207-2221.

TAYlor K.C., IN: Anderson M. J. R., Boudart M. (EDS.) (1984): Automobile Catalytic Converters. Catalysis Science and Technology, 5, Springer Verlag, Berlin. 119 p.

WeIsSERmel, K., ARPE, H.J. (1997): Industrial Organic Chemistry, 3rd ed., VCH, Weinheim. 439 p. 